DOI

\title{
ANTIOXIDANT SYSTEM OF RATS WITH HEAVY METALS AND PHOSPOORGANIC PESTICIDES INTOXICATION AND PEPTIDES APPLYING
}

The effect of peptide tsysteil-histidil-tyrosil-histidil-isoleucine on the state of antioxidant protection (superoxide dismutase, catalase) and lipid peroxidation has been reached. The peptide exhibits antioxidant activity, the correction of the peptide reduces free radical processes and decreases the products of lipid peroxidation and increases antioxidant enzymes activity.

KEY WORDS: reactive oxygen forms, lipid peroxidation, antioxidant system, the peptide.

INTRODUCTION. The saturation of cells by the oxygen and passing oxidation-reduction reactions in living organisms by generation of the active forms of oxygen (AFO) is accompanied. The AFO are free radicals, products of partial redaction of the atomic oxygen, and hydrogen peroxide, singlet oxygen, ozone, hypochlorite, peroxynitrite $[3,5]$.

The highly active AFO interact with various components of the cell: lipids, it is activated lipid peroxidation (LPO); DNA, causing decomposition of molecule and point mutations; proteins, forming covalent bonds with sum functional groups of proteins and destruction and polymerization of amino acid residues especially containing $\mathrm{SH}-$, $\mathrm{SCH}_{3}$-group of cysteine, methionine, $\mathrm{NH}$-groups of lysine leads, etc. [8].

There is system which inactivates active forms of oxygen - antioxidant system (AOS) in the living organism. This system protects the body and cells from the free radicals [3].

AOS is responsible for the regulation of the intensity free-radical formation reaction and inactivate processes of peroxidation products formation. Antioxidant system maintains a balance between the intensity of free radical formation and using them in the body. The age, sex, stress, etc. affects on the rate of lipid peroxidation products formation and antioxidant activity in the body [1-3, $14,15]$. There is oxidative stress if the balance between prooxidant and antioxidant systems are biased towards the first [2]. In most cases, this occurs while acute and chronic diseases, intoxication arise, injuries. Primary products of lipid peroxidation (LPO) are unstable substances, (c) Ye. B. Dmukhalska, Ya. I. Honsky, 2015 quickly break down with form secondary products of lipid peroxidation. Among them is well-known malonicdialdehyde (MDA). The accumulation of MDA explains formation of intoxication syndrome in the body that accompanies lots diseases of internal organs.

Oxidative systems generate primary active forms of oxygen (AFO) which inactivates AOC enzymes such as superoxidedismutase catalase and peroxidase. The first of these enzymes catalyzes the reaction superoxide dismutation of two molecules of hydrogen peroxide and oxygen. $\mathrm{H}_{2} \mathrm{O}_{2}$ is a substrate for peroxidase and catalase which neutralize it with formation water and oxygen.

The base of heavy metal activity is the inactivation of functionally active groups in structural proteins and protein enzymes, increased free radical oxidation and inactivate antioxidant [9].

Free amino acids and low molecular weight peptides inactivate free radical processes and they are a trap of free radicals [13].

The aim of research has been the study the peptide effect on antioxidant status and lipid peroxidation in rats of different age groups affected copper sulfate, acetate of lead and phosphoorganic pesticide - Roundup.

METHODS OF RESEARCH. We has been used lab nonlinear white rats - males three age periods: puberty (youth, 70-90 g body weight and 2 to 3 months age); mature (average, weighing 170-210 $\mathrm{g}$ and 5-8 months age) and old aging processes in which catabolic processes prevail over anabolic (body weight 250-300 g and 20-24 months age) animals to study the combined affected 
of lead acetate, copper sulfate, glyphosate and correction for peptide. Rats' age was determined by the scheme V. I. Makhinko and V. N. Nikytin [12].

Subhronic lesions in rats was modelled by intragastric administration of water solution of Lead Acetate at a dose of $11 \mathrm{mg} / \mathrm{kg}\left(1 / 20 \mathrm{LD}_{50}\right)$, Copper Sulfate at a dose of $13 \mathrm{mg} / \mathrm{kg}(1 / 20$ $\mathrm{LD}_{50}$ ), Glyphosate (in herbicide Roundup) at a dose of $250 \mathrm{mg} / \mathrm{kg}\left(1 / 20 \mathrm{LD}_{50}\right)$. Toxicants were administered in combination and individually. Dehlorinated drinking tap water to intact animals was added. The correction effect was research by the during 10 days intragastric administration of water solution of peptide tsysteil-histidil-tyrosilhistidil-isoleucine in a dose of $9 \mathrm{mg} / \mathrm{kg}$ body weight (concentration of amino acids in the blood) from $20^{\text {th }}$ day of the experiment after 6 hours after toxins. The peptides were synthesized at the Department of supramolecular chemistry and biochemistry Institute of High Technology of Taras Shevchenko Kyiv National University.

All animals were divided into the following groups: I - intact (controled); II - Copper sulfate affected; III - Lead acetate affected; IV - Glyphosate (Roundup); affected $\mathrm{V}$ - combination all toxicants listed affected; $\mathrm{VI}$ - corrected peptide. Euthanasia of rats was performed by bloodletting under the conditions of sodium thiopental anaesthesia on the $31^{\text {st }}$ day after intoxication by heavy metals, glyphosate and correction by peptide.
To study the peculiarities of free-radical oxidation and antioxidant defence system, the content of TBA-active products (TBA-AP) defined in [1], conjugated diene (CD) by [6]. We determined the activity of superoxidedismutase (SOD. 1.15.1.1 CE) by method [4]; catalase (CAT, CE 1.11.1.9) at [10].

All rats have been stayed on vivarium with stable temperature and humidity condition while the whole experiment [7].

For all indices the arithmetic mean of the sample (M), its variance and average error $(m)$ were calculated. The reliability of differences between the studied parameters was determined by using two-sample Student's t test [11].

RESULTS AND DISCUSSION. It is known that heavy metal poisoning and other xenobiotics are accompanied by the generation of AFO modification peroxide of molecules and depletion of antioxidant system of the body, which leads to increase in the content of lipid peroxidation products and decrease the activity of enzymes AOC [15].

The results of determination of the parameters of LPO and AOS in blood plasma and lever tissue homogenate of control group animals and rats with intoxication are presented in Table 1-2.

Activity of enzymes AOC (CT, SOD) decreased but content of MDA-active products and conjugated diene increased in the blood and liver of intact

Table 1 - Activity of superoxide dismutase (S.U./g protein) and catalase

(mkkat/g protein blood mkat/g protein liver) in the blood and liver of animals infected by lead acetate, copper sulfate, glyphosate and administrated of the peptide as correction factor $(M \pm m, n=10)$

\begin{tabular}{|c|c|c|c|c|c|c|c|c|}
\hline \multirow{3}{*}{ Age } & \multirow{3}{*}{\multicolumn{2}{|c|}{ Index }} & \multicolumn{6}{|c|}{ Animal Groups } \\
\hline & & & \multirow[b]{2}{*}{ Control } & \multicolumn{4}{|c|}{ Lesion } & \multirow{2}{*}{$\begin{array}{l}\text { Lesion and } \\
\text { peptide }\end{array}$} \\
\hline & & & & $\mathrm{CuSO}_{4}$ & $\left(\mathrm{CH}_{3} \mathrm{COO}\right)_{2} \mathrm{~Pb}$ & Glyphosate & $\begin{array}{c}\text { Combined } \\
\text { lesion }\end{array}$ & \\
\hline \multirow{4}{*}{$\begin{array}{l}\frac{t}{ \pm} \\
\frac{0}{J}\end{array}$} & SOD & $\begin{array}{c}\text { blood. } \\
\times 10^{3}\end{array}$ & $0.138 \pm 0.004$ & $0.127 \pm 0.003$ & $0.082 \pm 0.002$ & $0.124 \pm 0.004^{*}$ & $0.055 \pm 0.003^{\star}$ & $0.130 \pm 0.004^{\star \star}$ \\
\hline & & $\begin{array}{l}\text { liver. } \\
\times 10^{4}\end{array}$ & $0.586 \pm 0.018$ & $0.506 \pm 0.019$ & $0.466 \pm 0.023^{\star}$ & $0.478 \pm 0.018^{*}$ & $0.302 \pm 0.020^{*}$ & $0.536 \pm 0.019^{\star \star}$ \\
\hline & CAT & blood & $4.09 \pm 0.10$ & $3.33 \pm 0.11^{*}$ & $2.50 \pm 0.08^{*}$ & $2.80 \pm 0.12^{\star}$ & $2.38 \pm 0.10^{*}$ & $3.89 \pm 0.11^{\star \star}$ \\
\hline & & liver & $0.318 \pm 0.089$ & $0.247 \pm 0.010^{*}$ & $0.205 \pm 0.006^{\star}$ & $0.266 \pm 0.007$ & $0.189 \pm 0.007^{*}$ & $0.288 \pm 0.011^{\star \star}$ \\
\hline \multirow{4}{*}{ 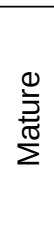 } & SOD & $\begin{array}{c}\text { blood. } \\
\times 10^{3}\end{array}$ & $0.116 \pm 0.005$ & $0.102 \pm 0.001$ & $0.088 \pm 0.002^{*}$ & $0.104 \pm 0.004$ & $0.071 \pm 0.003^{\star}$ & $0.110 \pm 0.003^{\star \star}$ \\
\hline & & $\begin{array}{l}\text { liver. } \\
\times 10^{4}\end{array}$ & $0.518 \pm 0.019$ & $0.470 \pm 0.020$ & $0.415 \pm 0.017^{*}$ & $0.459 \pm 0.014$ & $0.345 \pm 0.011^{*}$ & $0.508 \pm 0.019^{\star \star}$ \\
\hline & CAT & blood & $3.23 \pm 0.07$ & $3.00 \pm$ & $2.82 \pm 0.06^{*}$ & $2.94 \pm 0.04^{\star}$ & $2.57 \pm 0.08^{*}$ & $3.15 \pm 0.08^{\star \star}$ \\
\hline & & liver & $0.254 \pm 0.010$ & $0.181 \pm 0.007^{*}$ & $0.179 \pm 0.007^{*}$ & $0.192 \pm 0.007^{*}$ & $0.168 \pm 0.006^{*}$ & $0.238 \pm 0.0089 * \star$ \\
\hline \multirow{4}{*}{ 흥 } & SOD & $\begin{array}{c}\text { blood. } \\
\times 10^{3}\end{array}$ & $0.110 \pm 0.004$ & $0.091 \pm 0.005$ & $0.081 \pm 0.003^{*}$ & $0.090 \pm 0.003$ & $0.054 \pm 0.003^{\star}$ & $0.105 \pm 0.004^{\star \star}$ \\
\hline & & $\begin{array}{l}\text { liver. } \\
\times 10^{4}\end{array}$ & $0.454 \pm 0.016$ & $0.384 \pm 0.013$ & $0.363 \pm 0.013^{*}$ & $0.379 \pm 0.012$ & $0.228 \pm 0.010^{*}$ & $0.435 \pm 0.016^{\star \star}$ \\
\hline & CAT & blood & $2.93 \pm 0.06$ & $2.79 \pm 0.04$ & $2.05 \pm 0.06^{*}$ & $2.40 \pm 0.05^{\star}$ & $1.57 \pm 0.06^{*}$ & $2.85 \pm 0.08^{\star \star}$ \\
\hline & & liver & $0.221 \pm 0.004$ & $0.198 \pm 0.005$ & $0.171 \pm 0.005$ & $0.175 \pm 0.006^{*}$ & $0.111 \pm 0.004^{*}$ & $0.215 \pm 0.006^{\star \star}$ \\
\hline
\end{tabular}

Notes:

* - significant results relatively intact animals $(p<0.05)$.

** - significant results regarding performance in rats combined lesions $(p<0.05)$. 
animals with aging. These changes clearly reflect a general tendency to prevue cataboliticl processes in metabolism and accumulation AFO with age.

As it is shown by our exploration (Table 1), were observed changes catalase activity in blood serum of rats with copper sulfate, lead acetate, glyphosate and their combination lesion.

Thus, SOD activity decrease significant in blood plasma and liver homogenates of all age groups animals under the influence of xenobiotics (Table 1). There were recorded the maximum change of this index in blood by the combined action of toxicants and it was been at 3-month rats - 39.9\%, 6-month $62.2 \%$ and 18-month - $49.1 \%$, compared with intact animals. Similar changes of SOD activity in the liver, and it was in the 3-month animal $-48.1 \%$, 6-month - $66.6 \%$, 18-month - $50.2 \%$, compared with the control.

Such a decreasing SOD activity decreased can explained that lead ions, excessive concentration of cupper ions and glyphosate activate LPO processes and produced hydrogen peroxide formation, which is inhibitor of the enzyme. Spontaneous dismutation of superoxide radical reaction leads to the formation of $\mathrm{H}_{2} \mathrm{O}_{2}$ at the low SOD activity, which cells CAT decomposed. However, enzyme activity of catalase decreased in the blood and liver in animals with chemical liver affection.
It was observed the maximum decrease activity of this enzyme in old animals by the combined action of copper sulfate, lead acetate and glyphosate. It was higher on $53.6 \%$ and $50.2 \%$ (compere with the controls) in blood plasma and liver homogenate respectively.

We used the content of lipid peroxidation products - TBA-active products, conjugated diene (CD) for the exploration of free-radical oxidation processes, which often used in experiment and clinic.

The Table 2 represents the results of research content of TBA-active products in blood plasma and liver tissue intact and xenobiotics affected animals of all ages.

According to the data, the content of TBA-active products increases in healthy animals with age. Thus, it was (37.35 \pm 1.03$) \mathrm{mmol} / \mathrm{kg}$ in liver of puberty rets, it lest on 4.6 and $14.3 \%$ compared to the same period in Mature rats and old rats. Same change of TBA-active products we observe in blood plasma of puberty rets $(6.11 \pm 0.23) \mathrm{mmol} / \mathrm{l}(\mathrm{p}<0.05)$.

The content $C D$ increased in blood plasma and levels in all age groups animals by the affected all toxicants. The highest content CD was observed for combined action of all toxins. It was $181 \%, 158$ and $151 \%$ compere with the controls of normal in the 3-month, 6-month and 18-month rats. In blood

Table 2 - Containing of TBA-active products and conjugated diene in the blood and liver of animals lead acetate, copper sulfate, glyphosate affected and administrated of the peptide as correction factor $(M \pm m, n=10)$

\begin{tabular}{|c|c|c|c|c|}
\hline \multirow[b]{2}{*}{ Animal Group } & \multicolumn{2}{|c|}{ TBA-active products } & \multicolumn{2}{|c|}{ Conjugated diene } \\
\hline & blood. mmole/l & $\begin{array}{l}\text { liver. } \text { nmole } \mathrm{mg}^{-1} \\
\text { protein }\end{array}$ & blood. $\times 10^{3}$ S.U./I & liver. $\times 10^{3}$ S.U. $/ \mathrm{kg}$ \\
\hline \multicolumn{5}{|c|}{ Puberty } \\
\hline Control & $6.11 \pm 0.14$ & $37.4 \pm 0.8$ & $1.03 \pm 0.02$ & $5.40 \pm 0.16$ \\
\hline Lesion of $\mathrm{CuSO}_{4}$ & $7.76 \pm 0.14^{*}$ & $42.6 \pm 0.9^{*}$ & $1.38 \pm 0.03^{\star}$ & $6.49 \pm 0.22^{*}$ \\
\hline Lesion of $\left(\mathrm{CH}_{3} \mathrm{COO}\right)_{2} \mathrm{~Pb}$ & $8.62 \pm 0.12^{*}$ & $46.8 \pm 0.8^{\star}$ & $1.58 \pm 0.03^{\star}$ & $7.20 \pm 0.22^{\star}$ \\
\hline Lesion of Glyphosate & $7.18 \pm 0.14^{*}$ & $40.0 \pm 0.9^{*}$ & $1.29 \pm 0.02^{*}$ & $6.40 \pm 0.22^{*}$ \\
\hline Combined lesion & $9.18 \pm 0.09^{*}$ & $56.8 \pm 1.5^{\star}$ & $1.74 \pm 0.03^{*}$ & $9.77 \pm 0.22$ \\
\hline Lesion and peptide & $6.29 \pm 0.10^{\star \star}$ & $37.6 \pm 0.8^{\star \star}$ & $1.09 \pm 0.02^{\star \star}$ & $5.65 \pm 0.16^{\star \star}$ \\
\hline \multicolumn{5}{|c|}{ Mature } \\
\hline Control & $6.43 \pm 0.11$ & $39.1 \pm 0.7$ & $1.11 \pm 0.02$ & $6.24 \pm 0.16$ \\
\hline Lesion of $\mathrm{CuSO}_{4}$ & $6.86 \pm 0.12$ & $42.9 \pm 0.9$ & $1.38 \pm 0.04^{*}$ & $6.84 \pm 0.24$ \\
\hline Lesion of $\left(\mathrm{CH}_{3} \mathrm{COO}\right)_{2} \mathrm{~Pb}$ & $7.95 \pm 0.08^{*}$ & $47.6 \pm 0.9^{*}$ & $1.85 \pm 0.04^{*}$ & $8.24 \pm 0.21^{*}$ \\
\hline Lesion of Glyphosate & $7.5 \pm 0.09^{\star}$ & $45.0 \pm 0.9$ & $1.68 \pm 0.04^{*}$ & $6.52 \pm 0.24$ \\
\hline Combined lesion & $8.51 \pm 0.12^{\star}$ & $56.8 \pm 1.2^{*}$ & $2.11 \pm 0.02^{*}$ & $9.88 \pm 0.41^{*}$ \\
\hline Lesion and peptide & $6.53 \pm 0.10^{\star \star}$ & $40.0 \pm 0.7^{\star \star}$ & $1.16 \pm 0.03^{\star \star}$ & $6.47 \pm 0.19^{\star \star}$ \\
\hline \multicolumn{5}{|c|}{ Old } \\
\hline Control & $6.96 \pm 0.14$ & $42.7 \pm 0.8$ & $1.31 \pm 0.04$ & $7.14 \pm 0.15$ \\
\hline Lesion of $\mathrm{CuSO}_{4}$ & $8.66 \pm 0.19^{*}$ & $47.2 \pm 0.7^{*}$ & $1.80 \pm 0.06$ & $7.81 \pm 0.24$ \\
\hline Lesion of $\left(\mathrm{CH}_{3} \mathrm{COO}\right)_{2} \mathrm{~Pb}$ & $9.34 \pm 0.14^{*}$ & $51.8 \pm 0.8^{\star}$ & $2.61 \pm 0.06^{*}$ & $8.51 \pm 0.13^{*}$ \\
\hline Lesion of Glyphosate & $8.65 \pm 0.11^{*}$ & $47.8 \pm 0.8^{\star}$ & $2.11 \pm 0.04^{*}$ & $7.90 \pm 0.12$ \\
\hline Combined lesion & $10.75 \pm 0.14^{\star}$ & $70.9 \pm 0.8^{\star}$ & $2.91 \pm 0.08^{*}$ & $10.72 \pm 0.11^{\star}$ \\
\hline Lesion and peptide & $7.25 \pm 0.12^{\star \star}$ & $41.0 \pm 0.6^{\star \star}$ & $1.34 \pm 0.03^{\star \star}$ & $7.47 \pm 0.22^{\star \star}$ \\
\hline \multicolumn{5}{|c|}{$\begin{array}{l}\text { Notes. } \\
\text { * - significant results relatively intact animals }(p<0.05) \text {. } \\
\text { ** - significant results regarding performance in rats combined lesions }(p<0.05) \text {. }\end{array}$} \\
\hline & & & & \\
\hline
\end{tabular}


dynamics of conjugated diene had a similar trend. Thus, the maximum concentration of intermediate products of lipid peroxidation in the affected animals was observed by combined effects of xenobiotics.

The activity of free radical processes and antioxidant activity recovery after administration of peptide tsysteil-histidil-tyrosil-histidil-isoleucine of the lesion rats as correction factor, obviously, peptide is beneficial in antioxidant properties.
CONCLUSIONS. 1. 30-day intoxication by the copper sulfate, the lead acetate and the glyphosate form of Roundup in threshold doses $\left(1 / 20 \mathrm{DL}_{50}\right)$ is accompanied by increased activity of lipid peroxidation and inactivate antioxidant system, as it is evidenced by the growth of TBA-active products and inhibition activity of AOS enzyme.

2. The effect of peptide tsysteil-histidil-tyrosilhistidil-isoleucine on the state of antioxidant protection and lipid peroxidation.

\section{REFERENCES}

1. Андреева Л. И. Модификация метода определения перекисей липидов в тесте с тиобарбитуровой кислотой / Л. И. Андреева, Л. А. Кожемякин, А. А. Кишкун // Лаб. дело. - 1988. - № 11. - С. 4143.

2. Губерук В. О. Перекисне окиснення ліпідів та антиоксидантна система захисту організму (огляд літератури) / В. О. Губерук // Наук. вісн. Львівського НУВМБТ ім. С. 3. Гжицького. - 2008. - 10, № 3 (38), 4. 1. - С. 51-55.

3. Данчук В. В. Пероксидне окиснення у сільськогосподарських тварин і птиці / В. В. Данчук. Кам'янець-Подільський : Абетка, 2006. - 192 с.

4. Горячковский А. М. Клиническая биохимия в лабораторной диагностике / А. М. Горячковский. Одесса : Экология, 2005. - 607 с.

5. Заворотная Р. М. Синглетный кислород при лечении ряда патологических процесов: фризикохимические аспекты / Р. М. Заворотная // Укр. ревматол. журн. - 2002. - № 1. - С. 35-37.

6. Камышников В. С. Справочник по клиникобиохимической лабораторной диагностике / В. С. Камышников. - Минск : Беларусь, 2002. - Т. 1. - С. 546447.

7. Науково-практичні рекомендації з утримання лабораторних тварин та роботи з ними / Ю. М. Кожем'якін, О. С. Хромов, М. А. Філоненко, Г. А. Сайсретдінова. - К. : Авіцена, 2002. - 156 с.

8. Копытова Т. В. Окислительная модисрикация белков и олигопептидов у больных хроническими дерматозами с синдромом эндогенной интоксикации / Т. В. Копытова, О. Н. Дмитриева, Л. Н. Химкина // Фундаментальные исследования. - 2009. - № 6. С. 25-29.
9. Свинец и его действие на организм (обзор литературы) / А. И. Корбакова, Н. С. Сорокина, Н. Н. Молодкина [и др.] // Медицина труда и промышленная экология. - 2001. - № 5. - С. 29-34.

10. Метод определения активности каталазы / М. А. Королюк, Л. И. Иванова, Н. Г. Майорова, В. Е. Токарев // Лаб. дело. - 1988. - № 1. - С. 16-19.

11. Лакин Г. Ф. Биометрия / Г. Ф. Лакин. - М. : Высш. школа, 1990. - 352 с.

12. Махинько В. И. Константы роста и фрункциональные периоды развития в постнатальной жизни белых крыс / В. И. Махинько, В. Н. Никитин // Молекулярные и физиологические механизмы возрастного развития. - К., 1975. - С. 308-326.

13. Влияние карнозина и его $\mathrm{N}$-ацетильного производного на стабильность эритроцитов больных алкоголизмом в состоянии абстиненции / В. Д. Прокопьева, А. А. Бохан, П. Джонсон, А. А. Болдырев // Вопр. мед. химии. - 1998. - № 5. - С. 474-478.

14. Старик Л. І. Антиоксидантна система: природа, склад, механізми гомеостазу (огляд літератури) / Л. І. Старик // Наук. вісн. Львівської НАВМ ім. С. 3. Гжицького. - 2007. - 9, № 3 (34), ч. 2. C. $172-177$.

15. Frei B. Content of antioxidants, preformed lipid hydroperoxides and cholesterol as predictors of the susceptibility of human LDL to metal ion-dependent and independent oxidation / B. Frei, J. M. Gaziano // J. Lipid Res. - 1993. - 34. - P. 2135-2145.

16. Peroxiredoxin II is essential for sustaining life span of erythrocytes in mice / T. H. Lee, S. U. Kim, S. L. Yu [et al.] // Blood. - 2003. - 101. - P. 5033-5038. 
Є. Б. Дмухальська, Я. І. Гонський ТЕРНОПІЛЬСЬКИЙ ДЕРЖАВНИЙ МЕДИЧНИЙ УНІВЕРСИТЕТ ІМЕНІ І. Я. ГОРБАЧЕВСЬКОГО

\section{АНТИОКСИДАНТНА СИСТЕМА ЩУРІВ ЗА УМОВ ІНТОКСИКАЦІЇ ВАЖКИМИ МЕТАЛАМИ, ФОСФОРОРГАНІЧНИМ ПЕСТИЦИДОМ ТА ПРИ ЗАСТОСУВАННІ ПЕПТИДУ}

\section{Резюме}

Досліджено вплив пептиду цистеіл-гістидил-тирозил-гістидил-ізолейцину на стан системи антиоксидантного захисту (активність супероксиддисмутази, каталази) і процесів пероксидного окиснення ліпідів. Встановлено, що пептид проявляє антиоксидантну активність, про що свідчило зменшення вмісту продуктів процесів пероксидного окиснення ліпідів та відновлення активності фрерментів антиоксидантної системи.

КЛЮЧОВІ СЛОВА: активні форми кисню, пероксидне окиснення ліпідів, антиоксидантна система, пептид.

Е. Б. Дмухальская, Я. И. Гонский ТЕРНОПОЛЬСКИЙ ГОСУДАРСТВЕННЫЙ МЕДИЦИНСКИЙ УНИВЕРСИТЕТ ИМЕНИ И. Я. ГОРБАЧЕВСКОГО

\section{АНТИОКСИДАНТНАЯ СИСТЕМА КРЫС В УСЛОВИЯХ ИНТОКСИКАЦИИ ТЯЖЕЛЫМИ МЕТАЛЛАМИ, ФОСФОРОРГАНИЧЕСКИМ ПЕСТИЦИДОМ И ПРИ ПРИМЕНЕНИИ ПЕПТИДА}

\section{Резюме}

Исследовано влияние пептида цистеил-гистидил-тирозил-гистидил-изолейцина на состояние системы антиоксидантной защиты (активность супероксиддисмутазы, каталазы) и процессов пероксидного окисления липидов. Установлено, что пептид проявляет антиоксидантную активность, о чем свидетельствовало уменьшение содержания продуктов процессов пероксидного окисления липидов и восстановления активности фрерментов антиоксидантной системы.

КЛЮЧЕВЫЕ СЛОВА: активные фрормы кислорода, пероксидное окисление липидов, антиоксидантная система, пептид.

Received 27.05.15

Address for correspondence: Ye. B. Dmukhalska, I. Ya Horbachevsky Ternopil State Medical University, Maidan Voli, 1, Ternopil, 46001, Ukraine. 